\title{
Grief, resurrection, and the Nigerian Civil War in Isidore Diala's The Lure of Ash
}

\section{Solomon Awuzie}

\section{Grief, resurrection, and the Nigerian Civil War in Isidore Diala's The Lure of Ash}

As part of the third generation of Nigerian poetry, Isidore Diala's The Lure of Ash focuses on the Nigerian Civil War experience of 1967-1970, the grief associated with it, and the resurrection of the Biafran agitation. Being a collection that is derived from the rural world of the Igbo cosmology, Diala's The Lure of Ash portrays the Nigerian Civil War in a sensuous and emotive tone. It accounts for the poet's belief in the regeneration of the lives of the dead Biafran soldiers. The symbols of fire and ash are significant for interpreting the poet-speaker's grief in the collection. The collection also succeeds in painting a picture of the Nigerian Civil War experience where the bitter memory of the war resonates, while representing poetry as the healer of the pain and wounds of the war. Keywords: grief, resurrection, Nigerian Civil War, third generation Nigerian poetry, Isidore Diala.

Despite the very little attention Isidore Diala's The Lure of Ash (1997) has received from critics, the collection remains an important work of third-generation Nigerian poetry that addresses the Nigerian Civil War experience, the grief that is associated with it, and the resurrection of the Biafran agitation. ${ }^{1}$ Being a collection that was produced and published in the 1990s, a decade when Ralph Uwazurike, the leader of the Movement for the Actualisation of the Sovereign State of Biafra (MASSOB), rekindled the painful feelings associated with the Civil War by starting a nationwide radical campaign and agitation for Biafra, the collection reacts to this disposition by focusing on the resurrected Biafran agitation while drawing heavily from the grief of the war experience. ${ }^{2}$ The collection particularly forges a link between the resurrected Biafran agitation and the poet-speaker's imagination of the war experience through the use of grief as a major trope. However, grief is not a new trope in Nigerian Civil War poetry discourse in that it has persistently been used to reflect on the message of the futility of war. One of the reasons for this is that grief has the ability to calm the tension of the war that has continued to simmer even though the war ended fifty years ago. Also, grief has been used to attract sympathy to the victims of the war and to stress the effects of the war on the Biafran people. In Diala's The Lure of Ash, grief is engaged to paint a picture of the Nigerian Civil War in order to bear testimony to what 'really happened' and, in the words of Emmanuel Obiechina, to "ascribe distinct potency to poetry [...] as the healer of the self, the people and the wounded soul of [the] society in the harsh [and] bad times" (529).

The manipulation of grief has led to the categorization of Nigerian Civil War poetry as follows: one, poetry which focuses on people and places and, two, poetry which is derived from the local or rural world of Igbo cosmology and vegetation. The first category is found more among the poetry produced by the Hausa poets, much of it as a result of a 1968 poetry competition asking for poems in praise of the federal forces, and some poetry produced by the Yoruba and Mid-Western poets that seeks to calm the tension of the war (Furniss 21). While the Hausa poets exploit the three modes of Hausa oral and written verse, namely praise, vilification, and narrative, the little poetry produced by the Yoruba and Mid-Western poets expresses their bitterness over the war and the colossal waste in human and material resources. The second category of the Nigerian Civil War poetry refers to the poetry derived from local Igbo symbols, vegetation, and cosmology and has mostly been written by Eastern Nigerian poets. This poetry uses dominant animal images as well as some aspects of traditional mythology to symbolize the imagined Biafran nation. Diala's The Lure of Ash falls into this category. As a collection that is derived from the rural world of the Igbo cosmology, The Lure of Ash portrays the Nigerian Civil War in a sensuous and emotive tone. Through this

Solomon Awuzie is a senior lecturer in the Department of English, Faculty of Arts, Management and Social Sciences, at Edo State University Uzairue, lyamho, Nigeria.

Email: awuzie.solomon@edouniversity.edu.ng

(D) https://orcid.org/0000-0002-8239-7392

D0l: https://doi.org/10.17159/tl.v58i2.6793

DATES:

Submitted: 6 August 2019; Accepted: 1 September 2020; Published: 21 June 2021 
portrayal, the collection accounts for the poet's belief in the regeneration of the lives of the dead Biafran soldiers. The particular use of fire and ash as emotive symbols underlines the theme of grief, which, in addition to the experience of the Civil War itself and the more recent Biafran agitation, will be of central interest in this article.

In this article I show how Diala engages grief in the collection and reveals how he has used it to recreate the war experience in order to put the Biafran agitation in proper perspective. Not only does the poet-speaker's representation of the war experience evoke sympathy for the Igbo victims of the war, it also suggests that the Igbo war victims will be reborn to continue the Biafran agitation. Grief is used to reflect on the war as an unending experience in the mind of the poet. At the same time, the traditional Igbo lore, from which Diala extracted the philosophy that underlies this poetry, has rich emotive values and helps articulate a symbolic understanding of grief. Igbo lore presupposes a symbolic underpinning of everything: things are encrypted in symbols in order to create out of them a larger-than-life kind of meaning. Hence, grief is used to convey strong symbolic messages and to advance an Igbo belief in the regeneration of life-the same concept which Abba A. Abba explains as "the Igbo worldview", that is, a "worldview in which reincarnation is central in the conception of life and death" (2). He explains this further thus:

Igbo proverbial lore consistently draws attention to the caveat that life, salvaged and preserved, will be surrendered inevitably to death and that death is a debt which every human being owes to mother earth [...]. Although life brings a large measure of suffering, death is considered the greatest suffering of all; yet this apprehension of death in the Igbo worldview has given way to a new idiom in which death is reconstituted as a glorious becoming. The awareness of its ontological significance partly has led to the radical change in its perception as finality. (2)

Grief interrogates the Igbo worldview and questions its idea of the dead being reborn into an eternal circle of life. Diala explains this connection in his article entitled "Okigbo's Drum Elegies" when he posits that, in Igbo cosmic belief, death and bereavement speak volumes of human life and interrogate "humans' inward delusions of immortality" (93). Diala describes "the sublimation of the grief of bereavement into music" as a conquest and the "translation of the fear and pain of death" as an artistic triumph (93). He explains that. apart from the arrangement for the burial of a deceased, "a traditional Igbo burial ceremony, inspired by and rooted in the belief in reincarnation, typically constitutes a cosmic drama engaged in a sober reappraisal of life as a worthwhile experience even in the face and in defiance of death" (86).

It is for this reason that grief can be said to give the Igbo lore a certain aura of sacredness and potency, and that the association between grief and lore has been deployed in poetry as a tool to reflect on the wound of a devastating Nigerian Civil War experience. Grief has been reflected in Nigerian Civil War poetry to demonstrate "the power of poetry to distil from human catastrophes significant, unforgettable and redemptive truth" (Obiechina 531). In an inaugural lecture at Imo State University, Diala explained that the reason for this portrayal in poetry is to underscore the fact that "writers pay close attention to war given its proclivity to foreground experiences that underline the abiding paradox of the human situation: the grandeur of the human spirit and the mortality of the human condition, human capacity for heroism, and will for unbridled evil to which war also gives full rein" (Dionysos, Christ, Agwu and the African Writer 47). Hence Diala is able to reflect on the war in such a way that not only the memory of the experience of the war is represented, but the activities of the Biafran leader-turned-heroand-legend, Odumegwu Ojukwu, during the war are also celebrated. It is for this reason his account of the war experience transcends the immediate response to the Civil War. As a matter of fact, he uses The Lure of Ash to reveal the healing that must follow because of the peculiarities of the war and to stress the capacity of poetry to help heal the wound of the war. The poet-speaker imagines the possibility of healing the wounds of the Civil War by addressing important lingering issues: the many Biafrans who laid down their lives in defense of their homestead, the futility of war and the wasted energies that were put into it, and, finally, the enduring impact of the conflict in the country's socio-political landscape. With all of these ills in mind, the collection advances the idea of regeneration in order to promote the poet-speaker's belief in the rebirth of all who died in the war. Since the Nigerian Civil War experience produced sorrow, the mood of the Igbo poets who focus on it reflects grief. As such, grief has continued to resurface in the Nigerian Civil War poetry produced by the Igbo poets.

In order to capture these aspects of the war, The Lure of Ash is divided into three subsections: "The hues of ash", "The swell of ash", and "The trail of ash". All are woven together to reflect on the theme of grief. While "The hues of ash" begins by exalting the idea of death during the Civil War as creative rebirth, "The swell of ash" contemplates the activities of the Biafran forces as acts of self-preservation as well as the vicissitudes of life through grief. "The 
trail of ash", on the other hand, reflects on Amadioha as the symbol of the Biafran army. Amadioha in the Igbo pantheon is a god of justice and of a consuming fire: it protects the morally upright supplicant and avenges the wrong that is done to him. Hence it is replicated among some Igbo Christians as the "holy ghost fire". In the poem entitled "The priest and the pilgrim", Amadioha is described as the Biafran Army "who with bare hands" is capable of wreaking havoc on the Nigerian space by killing many federal Nigerian soldiers at the slightest provocation. For this reason, it is expected that Amadioha be given the right military hardware, i.e. heavy arms, to do the job it is good at doing. This is evident in the line where the poet-speaker expresses his worry that instead of heavy arms, Amadioha was offered "a blunt cutlass", in reference to the under preparedness of the historical Biafran army (The Lure of Ash 47). ${ }^{3}$

The critical disposition of the poet towards the war is strongly portrayed in the collection through his constant reference to Amadioha as well as his frequent use of "fire" and "ash" as symbols. While fire as a symbol in the collection refers to the 'white light' which Amadioha bellows, ash connects to death: it represents that state of nothingness which every material thing must return to. It is a symbol that signals the death of the soldiers on both sides as well as the destruction of property. Ash is also used to refer more specifically to the death of Biafran soldiers: it indicates that their death, already contemplated as a loss, would change its state by transcending into a glorious reawakening. It depicts the significance of death as the primordial creative rebirth. With this, the collection forges a very important link with Diala's play The Pyre, where death is presented as the end to one phase of life and the beginning of the eternal circle of life. For this reason, the dead Biafran soldiers are represented as the ogbanje haunting the Nigerian nation until they can be reborn. ${ }^{4}$ Given the level of death and destruction, The Lure of Ash justifies the Igbo proverb that Onwu anagi eshi ama, which means "death does not end a race". The entire collection seems to illustrate this proverb.

This revelation is first made in the collection with the poem entitled "Ululation". The poem explains how the Nigerian Civil War, represented through the symbol of fire, caused the death of many who were forced to defend themselves as a result of the exigencies of the war. It also expresses the belief in the generation of the dead Biafrans reborn to advance the agitation for 'Biafra' as ideal or idealized nation. The poet-speaker maintains that mourners' grief for the dead during the war softens the creation clay; hence death during the war represents "home-going" which must spiral into "home-coming". This is captured in the lines where the poet-speaker says: "The grave like the yam-mound is earth's pregnancy: / Life like a dance swings in circles" (Lure 3). The poet-speaker also notes that every birth song afterwards is the call of the race to the Biafran soldiers who are still in the afterlife to return. This is evident in the line where the poet-speaker posits: "The birth song is our call to eternity" (3). The poet-speaker stresses his faith in the ability of the generations of the reborn army to recreate the dream of the ideal nation, which he describes in "The Beckoning" as "the inspiring dream" (Lure 15). The grief that runs through "Ululation" is also expressed in the poem entitled "Earth's Lament". This poem laments the bloodbath and tears that characterised both the Nigerian Civil War and the present Nigerian landscape. In this poem, this situation is expressed in the lines thus: "Grief is incarnate as a bereaved mother's tears" and "Earth wails in fierce shudders of rebirth" (Lure 8). In "The Awaited", the poet-speaker prays that his faith in the generation to be reborn and in the ideal nation should not be in vain. He prays that the "eye" that experienced the killings and the destruction during the war may "behold the divine event" of the Biafran agitation "[b]lazing forth in spectacular flames on the holy pyre" (Lure 49). The grief in the poem reflects especially on the killings and destruction of property belonging to the Igbo during and after the Nigerian Civil War.

Throughout the collection, the poet-speaker reiterates the gory emphasis that characterizes the third generation of Nigerian Civil War poetry. In various poems, The Lure of Ash makes repeated references to Christopher Okigbo - the prominent Nigerian poet of the first generation, a civilian who was commissioned a major by the Biafran government, and who died defending the homestead - in order to stress Diala's belief and faith in the generation of the dead Biafrans who will be mystically reborn to continue the struggle for justice. In most of the poems, the poet-speaker contemplates Christopher Okigbo's sacrifice as well as those of other prominent Biafran soldiers. These include Major Chukwuma Nzeogwu, one of the five majors who led the first Nigerian coup of 1966 and who died defending Biafra, and Major General Johnson Aguiyi-Ironsi, the first Nigerian military head of state, who was killed in the countercoup of the same year. In one poem entitled "Okigbo's Quarter Century Sleep", where the poet-speaker expresses his faith in Okigbo's reawakening, he notes that Okigbo and all other Biafran soldiers who laid down their lives in defense of their homestead did not die in vain. In the same poem he expresses his belief in the death of the Biafran soldiers as a re-enforcement, which must come, as he puts it in "The Beckon- 
ing", after the "weary pilgrim [...] [a]cross the timeless realms of dreams" (15). He explains that, for instance, even though Okigbo died during the war, dust is only the curve where his flesh reclines and that his immortality is assured. The poet-speaker affirms his faith in Okigbo being reborn to further unclasp "the unborn truth wrapped in the folds of mystery" (9). The faith he has for Okigbo underscores his penchant for the dead Biafran soldier in the last stanza of the poem entitled "The Beckoning":

I sing you Okigbo of the Ogene voice

That trod the path of thunder on the night of steel

And like the flaming god himself, to blaze the truth,

Burned too intensely and merged with the undying light. (Lure 9)

In this stanza, the poet-speaker celebrates Okigbo for joining the war. Like Jesus Christ, Okigbo's sacrifice in the war is redemptive.

The poet-speaker sees Okigbo's death in the war as revealing how justified the war was, for the people of the former Eastern Nigeria were left with no option but to defend their homestead, even though it meant fighting with bare hands and naked bodies. This is also reiterated in "On a Tombstone", where he praises Okigbo for laying down his life in defense of the ideal nation, Biafra. He refers to Okigbo in the poem as the light and the signpost to the living and hopes that Okigbo makes eternal allies with others who died in the war and who are still in the world beyond. In a parallel way, in "Nzeogwu's Epitaph", Chukwuma Nzeogwu is also praised for fighting in the war. The poet-speaker describes Nzeogwu as a soldier who "sought to extract / The ash in the fl-ash of light" (Lure 11). In this poem, ash, for the first time, refers to corruption and thunder signifies the 1966 coup that brought the military into the Nigerian political arena. In the poem, Nzeogwu is represented as having joined the war because he believed that the people of the former Eastern Nigeria were fighting a just war. This informs the reasons his name is included as one of the names that were celebrated during the war, which is evident in the poem's title.

The point is further emphasized in "Warrior's Chant", where the poet-speaker describes the thirty thousand Eastern Nigerian people who were slaughtered in the Northern Nigerian massacre before the war. Ironsi, Nzeogwu, and Okigbo, all seen as Biafran martyrs, are described as "Enyie Biafra", which literarily translates to "Biafran elephants" (Lure 54). In "Warrior's Chant", the death of these Igbo soldiers and many civilians-turned-soldiers during the war is commemorated in a way that reminds the reader of the hostilities that preceded the war. The poem sings of the communion of the dead soldiers and the awakening of the Eastern Nigerian people represented in the poem as the deprived. It expresses the hope that one day the decades of grievances of the people will lead to a stronger agitation for the Biafran dream because "no more shall silence speak our endorsement of tyranny" (56). In the poem, the activities of the federal forces during the Civil War are engaged through the use of the fire symbol, which ultimately represents killing and destruction. This is accompanied with the use of the ash symbol, which is also a symbol of death. In order to pursue the paradoxes that are inherent in these symbols, the poet-speaker appropriates some of Okigbo's enigmatic poetic styles. His play on symbols to contemplate the war experience in the poem runs like a very beautiful sorrow song that is difficult to communicate. Of course the use of this poetic style is not limited to the poem: it runs through most of the poems of the collection. In other words, this makes Diala, to use a description that has been applied to Okigbo, to "appear confused, carried away by music and [sometimes] forgetful of his failure to make sense" (Egudu 153). This somewhat cryptic quality explains why Diala's poetry has not received the kind of attention it deserves despite its beauty, alternating as it does between a cry and sorrowful music.

The poem entitled "Rites of Flame" describes the war and the deaths it caused as an "apocalyptic fire rage" (Lure 22). The poet-speaker sees the communities during the war as a place where earth, air, and sea reek of dead bodies and where death unrolls its "cleansing tongue like a flaming scythe" (22). In "A Voice From Zango-Kataf", the poet-speaker laments that the killings are not limited to wartime. They have continued and become a day-today Nigerian occurrence long after the end of the war. The poem particularly focuses on the many riots that took place in the 1990s in the Northern part of the country, where many Igbo people were killed. The poet-speaker grieves over these deaths. He posits that, while the dead were alive, the country never showed any form of care towards them. He describes how those Igbo people suffered to make ends meet and in the mix of their suffering they were consumed in the many Northern Nigerian massacres of the 1990s. Traversing all these in a country which is also theirs and struggling to come to terms with their conditions, they were "touched by the bliss of eternity" and their lives "mercifully sealed by the grave silence of death" (Lure 17). In this same poem, the poet-speaker stresses 
that the lifeless bodies of the victims who were murdered in the massacres will forever remain perfect insofar as "they will never again howl for bread" (17). The poem emphasizes the ethnic unrest that took place during those years as a continuation of the Civil War in order to reflect on the collective disenchantment with the socio-political realities of the present Nigerian state.

In "Forbidden Ascent", the poet-speaker recalls the many Igbo who died in the notorious and suspicious plane clash in Ejigbo, near Lagos, in 1992. He laments that, after the crash, he hears his kindred crying. He hears the same funeral chants he recognizes. He sees their "ash-bespattered faces / Gazing forever forlorn into the vacant sky" (Lure 18). Like "A Voice From Zango-Kataf", this piece deplores the fate of the Igbo in the Nigerian federation even in the decades after the war. It describes the Nigerian nation as a pyre that is always ablaze and a place where Easterners, particularly Igbo, are always fed "to a cruel flame". In another line, the country is described as "one vast anxious tomb" where the people are "the elect heirs of martyrdom" (18). In "Invocations", the poet-speaker posits that, years after the war, there have been many cases of killings and violence against the Eastern Nigerian people. Hence the poet-speaker prays and hopes that he and his people be saved "From the plumage of hollow laughters / Forged in the seething ore of hate" (Lure 4). He also prays that his people may witness a genuine change that will put the traumatic memories of death and destruction to rest.

Finally, it is important to note that the collection seems to call for the resurrection of the Biafran nationperhaps symbolically, but with clear political overtones. Perhaps most explicitly, "Rites of Flame" expresses a faith in Biafra's reawakening by exclaiming, "Let the dying nation wake" (Lure 22). In a more enigmatic register, "Worksong" addresses the watery deity of the River Niger and laments the ongoing plight of the Igbo in the Nigerian federation. The poet-speaker tells of the Biafran scar and how the Igbo survivors of the war were deprived of all their belongings. He restates his faith in the reawakening of the Biafran dream and affirms that, despite its challenges, this dream will live:

But the kite swoops on the burning bush

seeking its mother in vain;

The vulture takes the legendary bath

that deepens its ugliness;

The snake rears and strikes the fabulous tortoise

cracks its fangs on the carapace. (Lure 7)

The lines that make up the above stanza capture the attempts by successive Nigerian governments to frustrate the Biafran agitation and how the attempts have all ended in futility. The poet-speaker represents the successive Nigerian governments in different symbols. First is the symbol of the kite, followed by the symbol of the vulture, and the symbol of the snake. In all three attempts, Nigeria is imagined as a predator that has failed to kill its prey. Since the nation is always seeking Biafran people's reaction by constantly bringing war to them, these lines seem to assure the reader that the prey, the "fabulous tortoise", one day answers to the savage call by destroying the predator. The claim is further expressed with the use of the symbol of the "fallow forest", which emphasizes a reawakening inner human: "The man in us answers the call of the fallow forest" and "clears the path to the ancestral barn" (Lure 7). The poet-speaker notes with all finality that, though the people "wear the morning dew like a crown", they will one day reawaken the dying ideal nation.

In the last poem of the collection, entitled "My chant", the poet-speaker summarizes the message of the entire collection in three stanzas, thus:

My chant is the flame

Around which suppliants keep uneasy vigil,

Garnering an avalanche of ash and tears

My chant is a dirge

Blossoming in caverns of grief

Wailing, wailing for the resurrection.

My chant is the voice

Of my country - a ravished amputee-

Shrieking for the healing herb,

Wailing for crutches of reed. (63) 
In these stanzas the poet-speaker refers to the whole of The Lure of Ash as "my chant". In the first stanza he posits that the collection serves as a medium through which Eastern Nigerian people are reminded about what happened to them during the war. He describes his poetry as the "flame" which reignites their memories of the war. In the second stanza he describes the collection as a dirge that comes alive as one remembers or imagines the anguish of the people during the war. This anguish has made the people nostalgic for the Biafran dream that animated the war in the first place. The last stanza casts The Lure of Ash as the voice through which the Biafran nation, though battered, can still be heard. Even though the nation is "a ravished amputee", it is reaching for "the healing herb" and the "crutches of reed". The poet-speaker is hopeful that this poetry will advance the cause for healing. The pains and the wounds of the war have yet to heal; they have festered and need attention. The fact that the Nigerian nation is home to irresponsible successive governments that have continued to fan the embers of disunity leave one to wonder whether this healing is possible.

\section{Notes}

1. Even though the use of the term "generation" as a marker in Nigerian literary landscape has been criticized by Harry Garuba, who is of the view that the term results in the problem of thematic fluidity and temporal overlaps (51), the term has been upheld as a useful term for repositioning and for foregrounding tropes in Nigerian literary terrain. The third generation is "widely believed to have been announced by and in the 1988 anthology entitled Voices from the Fringe: An ANA Anthony of New Nigerian Poets, edited by Harry Garuba" (Egya 426). The term "generation" was first used by a group of Nigerian writers to announce the focus of their writing as a continuum in the production of postcolonial Nigerian literary tradition. This group of writers was led by Niyi Osundare, Kole Omotoso, and Femi Osofisan (Currey 52). These writers described Chinua Achebe and Christopher Okigbo as belonging to the first generation and themselves as the second. While they accuse Achebe and Okigbo's generation as being "too concerned with explaining Africa to Europeans" (52), they note that their own writings would be concerned with Africa's "contemporary social and political reality and must explain Africa to Africans" (52). Sule Egya describes the poets of the third generation as poets that are "engaged, by birth, by circumstances, by comradeship, and most importantly by personal will in a cultural struggle in the sense prescribed by their precursors" (426). Pius Adesanmi and Chris Dunton describe third-generation Nigerian literature as "texts born into the scopic regime of the postcolonial and the postmodern" (15; see also Ushie 11). They also see it as "an order of knowledge in which questions of subjecthood and agency are not only massively overdetermined by the politics of identity in a multicultural and transnational frame but in which the tropes of Otherness and subalternality are being remapped by questioning erstwhile totalities such as history, nation, gender, and their representative symbologies"

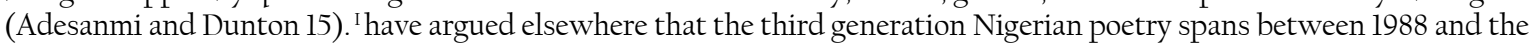
present and that the generation is of two parts (Awuzie 82). The first part is the early third generation. It is between 1988 and 1999 and pertains to military despotism and its corrupting influence on the country. The second part is the latter third generation and it is between the year 2000 and the present. It concerns the corrupt civilian regimes and lampoons the level of corruption in the country.

2. A nation that was declared by Colonel Chukwuemeka Odumegu Ojukwu, the then governor of the former Eastern Nigeria, in response to the massacre of the Igbo in the North. Biafra ceased to be a nation in 1970 when its armed forces lost to the Nigerian federal forces. Since the end of the war in 1970, there has been a continuous Biafran agitation and this has been met with serious military crackdown by the Nigerian government. Among the leading organizations in the frontline Biafran agitation are the Movement for the Actualization of the Sovereign State of Biafra (MASSOB) led by Ralph Uwazurike and the Indigenous People of Biafra (IPOB) led by Nnamdi Kanu.

3. Parenthetical citations from The Lure of Ash refer to page numbers, not line numbers.

4. Ogbanje is an Igbo word that refers to a child who alternates between the land of the spirits and the land of the living.।

\section{Works Cited}

Abba, Abba A. "Birth, Death and Re-birth: The Trope of Eternal Rejuvenation in Isidore Diala's The Lure of Ash." The Journal of Commonwealth Literature, 2018, pp. 1-15. DOI: https://doi.org/10.1177/0021989418773138.

Adesanmi, Pius \& Chris Dunton. "Nigeria’s Third Generation Writing: Historiography and Preliminary Theoretical Considerations." English in Africa vol. 32, no. 1, 2005, pp. 7-19. https://www.jstor.org/stable/40239026.

Awuzie, Solomon. "Mirroring the Society, Mirroring its Hospital: Hyginus Ekwuazi's Poetry and the Challenge of NationBuilding." English Studies at NBU vol. 5, no. 1, 2019, pp. 77-91. DOI: https://doi.org/10.33919/esnbu.19.1.4.

Currey, James. Africa Writes Back: The African Writers Series and the Launch of African Literature. James Currey; Ohio U P; HEBN, 2008.

Diala, Isidore. Dionysos, Christ, Agwu and the African Writer. Imo State U P, 2019.

The Lure of Ash. Nok International, 1997.

"Okigbo's Drum Elegies". Research in African Literature vol 46, no 3, 2015, pp 85-111. DOI: https://doi.org/10.2979/ reseafrilite.46.3.85.

Egudu, Romanus. "Ezra Pound in African Poetry: Christopher Okigbo." Comparative Literature Studies vol. 8, no. 2, 1971, pp. 143-54. https://www.jstor.org/stable/40467936.

Egya, Sule E. "Historicity, Power, Dissidence: The Third-Generation Poetry and Military Oppression in Nigeria." African

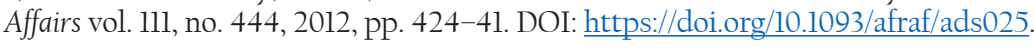


Furniss, Graham. "Hausa Poetry on the Nigerian Civil War." African Languages and Cultures vol. 4, no. 1, 1991, pp. 21-8. https:// www.jstor.org/stable/1771678.

Garuba, Harry. "The Unbearable Lightness of Being: Re-figuring Trends in Recent Nigerian Poetry." English in Africa vol. 32 , no. 1, 2005, pp. 51-72. https://www.jstor.org/stable/40239029.

Obiechina, Emmanuel. "Poetry as Therapy: Reflections on Achebe's Christmas in Biafra and Other Poems." Callaloo vol. 25, no .2, 2002, pp. 527-58. https://www.jstor.org/stable/3300585.Ushie, Joe. "Phases in Nigerian Poetry in English." New Nigerian Poetry vol. 3, no. 1, 2005, pp. 11-25. 